\title{
A global antiB cell strategy combining obinutuzumab and daratumumab in severe pediatric nephrotic syndrome
}

\author{
Claire Dossier $^{1}$ - Benjamin Prim ${ }^{1} \cdot$ Christelle Moreau $^{2}$ - Thérésa Kwon ${ }^{1} \cdot$ Anne Maisin ${ }^{1} \cdot$ Sylvie Nathanson ${ }^{3}$. \\ Christiane De Gennes ${ }^{4} \cdot$ Katia Barsotti $^{5}$. Abdelmajid Bourrassi ${ }^{6}$. Julien Hogan ${ }^{1} \cdot$ Georges Deschênes $^{1}$ (I)
}

Received: 3 March 2020 / Revised: 18 September 2020 / Accepted: 2 October 2020 / Published online: 28 October 2020

(C) IPNA 2020

\begin{abstract}
Background Steroid-sensitive nephrotic syndrome (SSNS) is, in most patients, a chronic disease with $80 \%$ experiencing at least one relapse after first flare. B cell depletion using rituximab is effective in preventing relapse in steroid-dependent (SDNS) patients but fails to maintain long-term remission following B cell recovery, possibly due to development of autoreactive long-lived plasma cells. We investigated sequential combination of antiCD20 antibody targeting all B cell subsets, and antiCD38 antibody with high plasma cell cytotoxicity in patients with uncontrolled SDNS after failure of one or several attempts at B cell depletion.

Methods Fourteen patients with median disease duration 7.8 years received $1000 \mathrm{mg} / 1.73 \mathrm{~m}^{2}$ obinutuzumab followed by $1000 \mathrm{mg} /$ $1.73 \mathrm{~m}^{2}$ daratumumab 2 weeks later. Oral immunosuppression was discontinued within 6 weeks, and biological monitoring performed monthly until B cell recovery.

Results Median age at treatment was 11.0 [IQR 10.4-14.4] years. B cell depletion was achieved in all patients, and B cell reconstitution occurred in all at median 9.5 months after obinutuzumab injection. After median follow-up 20.3 months (IQR 11.5-22.6), 5/14 patients relapsed including 4 within 100 days following B cell repletion. Relapse-free survival was $60 \%$ at 24 months from obinutuzumab infusion. Mild infusion reactions were reported in 3/14 patients during obinutuzumab and 4/14 during daratumumab infusions. Mild transient neutropenia $\left(500-1000 / \mathrm{mm}^{3}\right)$ occurred in $2 / 14$ patients. Intravenous immunoglobulins were given to $12 / 14$ patients due to hypogammaglobulinemia. Low IgA and IgM levels were noted in 8 and 14 patients, respectively. No severe infection was reported. Conclusion Global antiB cell strategy combining obinutuzumab and daratumumab induces prolonged peripheral B cell depletion and remission in children with difficult-to-treat SDNS.
\end{abstract}

Keywords Children · Steroid-dependent nephrotic syndrome $\cdot$ Rituximab $\cdot$ Relapse $\cdot$ Obinutuzumab $\cdot$ Daratumumab $\cdot$ B cell recovery

\section{Background}

Although the majority of children with idiopathic nephrotic syndrome (INS) are steroid sensitive (SSNS), $80 \%$ of them

Electronic supplementary material The online version of this article (https://doi.org/10.1007/s00467-020-04811-0) contains supplementary material, which is available to authorized users.

\section{Georges Deschênes}

georges.deschenes@aphp.fr

1 Department of Pediatric Nephrology, Hôpital Robert-Debré and Universty of Paris, Paris, France

2 Department of Pharmacy, Hôpital Robert-Debré and University of Paris, Paris, France

3 Department of Pediatrics, Hôpital André Mignot, Le Chesnay, France will experience relapses and a chronic evolution of the disease [1]. A significant proportion of frequent relapsers (FRNS) and steroid dependent (SDNS) will have a protracted course exceeding 10 years and be exposed to oral prednisone and
4 Department of Pediatrics, Centre Hospitalier Nord Essonne, Orsay, France

5 Department of Pediatrics, Groupe Hospitalier La Rochelle, La Rochelle, France

6 Department of Pediatrics, Centre Hospitalier et Universitaire de la Martinique, Fort-de-France, France 
immunosuppressive drugs beyond adult age [2]. The endless succession of relapses and the many complications of both the disease and the exposure to immunosuppressive drugs explain the morbidity of INS and impose major constraints on the patients.

Immunosuppressive drugs have been used to reduce exposure to steroids and their toxicity in FR/SDNS. Levamisole, cyclosporine, mycophenolate mofetil, cyclophosphamide, and more recently monoclonal antibodies specifically targeting B cells, like rituximab, have demonstrated their ability to prevent relapses [3]. All these drugs are known to alter B cell immunity. Among them, cyclophosphamide and rituximab deserve special attention since they have a remnant effect, leading to a stable remission far beyond the withdrawal of the treatment in some patients [4-7]. Cyclophosphamide mainly targets naïve B cells and immature short-lived plasma cells, but not memory B cells $[8,9]$. By contrast, rituximab affects the survival of naïve and memory B cells, but does not affect long-lived plasma cells [10]. Consistently, the failure of rituximab to control autoimmune diseases has been attributed to the development and/or survival of autoreactive long-lived plasma cells. The production of these plasma cells is paradoxically increased in the context of B cell depletion [11] and associated to the chronicity of autoimmune diseases. Of note, measles has been historically associated with temporary or definitive remission of childhood nephrosis $[12,13]$, in that it induces the depletion of both memory T and B cells, and also plasma cells [14].

This retrospective study reports the outcomes of difficultto-treat SDNS patients, who relapsed after rituximab and were treated with a global antiB cell strategy targeting both B cells and plasma cells. The treatment sequentially combined obinutuzumab (OBI), a second generation antiCD20 monoclonal antibody targeting naïve and memory B cells, and daratumumab (DAR), an antiCD38 monoclonal antibody targeting plasma cells. This combination aimed to control the development of autoreactive long-lived plasma cells in patients where B cell depletion alone failed to provide sustained remission.

\section{Methods}

This is a monocentric retrospective study including SDNS patients who relapsed after rituximab and were treated with a sequential combination of obinutuzumab and daratumumab (referred to below as the OD sequence) at Robert-Debré Hospital, APHP, Paris, from June 2018 to July 2019.

A single intravenous dose of obinutuzumab $1000 \mathrm{mg} /$ $1.73 \mathrm{~m}^{2}$ (a reduced dose of $300 \mathrm{mg} / 1.73 \mathrm{~m}^{2}$ in one patient) over $4 \mathrm{~h}$ was injected at day 0 . At day 14 , patients received an injection of daratumumab $1000 \mathrm{mg} / 1.73 \mathrm{~m}^{2}$ over $4 \mathrm{~h}$. Before each infusion, patients received systematic premedication with acetaminophen $(15 \mathrm{mg} / \mathrm{kgBW})$, methylprednisolone
(1 $\mathrm{mg} / \mathrm{kgBW})$ and dexchlorpheniramine $(2.5 \mathrm{mg}$ below 30 $\mathrm{kgBW}$ and $5 \mathrm{mg}$ over $30 \mathrm{kgBW}$ ). In addition, oral prednisone at a dose of $20 \mathrm{mg} /$ day was given for 2 days after daratumumab infusion. Oral immunosuppression withdrawal was scheduled as follows: prednisone was maintained at $60 \mathrm{mg} / \mathrm{m}^{2}$ every other day for 2 weeks after obinutuzumab injection then tapered down to $30 \mathrm{mg} / \mathrm{m}^{2}$ every other day for 2 weeks then stopped; tacrolimus was maintained at the same dose 4 to 6 weeks after obinutuzumab injection and stopped. All patients received sulfamethoxazole $(800 \mathrm{mg} \times 3 /$ week $)$ during B cell depletion. A monthly follow-up of proteinuria, serum creatinine and albumin, white blood cells, platelets, and CD19 counts, as well as plasma levels of immunoglobulins G, A, and $\mathrm{M}$, was scheduled.

All data were collected from routine clinical and biological reports. Off-label prescription of the OD sequence has been approved by our institution's "Drug Committee". Parents as well as patients over 18 years signed an informed consent of care.

Patients' medical history and characteristics at baseline are individually reported in Tables 1 and 2, using median and interquartile range (IQR) when mentioning the whole series. Time to B cell reconstitution and relapse-free survival were studied using the Kaplan-Meier method, and the evolution of concentrations of immunoglobulins over time was studied using the weighted least square method.

\section{Results}

\section{Patient history}

Fourteen patients with SDNS were treated (Table 1) including 13 males and one female. Median age at the first flare was 3.2 years (interquartile range IQR 1.9-5.4). Steroid sensitivity was defined at first flare by a proteinuria $<0.02 \mathrm{~g} / \mathrm{mmol}$ of urine creatinine after 4 weeks of oral prednisone $\left(60 \mathrm{mg} / \mathrm{m}^{2} /\right.$ day) in 11 patients and after 3 additional pulses of intravenous methylprednisolone $\left(1000 \mathrm{mg} / 1.73 \mathrm{~m}^{2} /\right.$ pulse $)$ in 3 patients (\#4,\#5,\#11). All patients had a history of steroid dependency (relapses under 5-60 mg of alternate day regimen of prednisone). The course of 4 patients (\#4,\#5, \#10,\#14) after the first flare was also complicated with one episode of secondary steroid resistance, but all those patients demonstrated steroid sensitivity during later relapses prior to obinutuzumab injection. Of note, 4 patients experienced an extended duration of the disease with persistent relapses later than 10 years after INS onset (\#4,\#6,\#7,\#13). All patients were previously treated with oral treatments including levamisole in 8 patients, cyclophosphamide in 3 , and mycophenolate mofetil in 12 , and either cyclosporine or tacrolimus in 13. Medical adherence, assessed by the patients' physicians, was considered poor in 1 patient, partial in 2 and appropriate in 11 . All patients 
Table 1 History of patients and previous treatments prior to the injection of obinutuzumab

\begin{tabular}{|c|c|c|c|c|c|c|c|c|c|c|c|}
\hline $\begin{array}{l}\# \\
\text { Patients }\end{array}$ & Gender & $\begin{array}{l}\text { Age at } \\
\text { INS } \\
\text { onset } \\
\text { (years) }\end{array}$ & $\begin{array}{l}\text { IVMP } \\
\text { at } 1 \mathrm{st} \\
\text { flare } \\
(n)\end{array}$ & $\begin{array}{l}\text { Number } \\
\text { of } \\
\text { relapses } \\
(n)\end{array}$ & $\begin{array}{l}\text { Level of } \\
\text { steroid } \\
\text { dependence } \\
\mathrm{mg} / 48 \mathrm{~h}\end{array}$ & $\begin{array}{l}\text { Late } \\
\text { steroid } \\
\text { resistance }\end{array}$ & History of IS drugs & $\begin{array}{l}\text { B cell } \\
\text { depleting } \\
\text { agents }\end{array}$ & $\begin{array}{l}\text { B cell } \\
\text { depletion } \\
\text { (number of } \\
\text { attempts) }\end{array}$ & $\begin{array}{l}\text { Cumulative } \\
\text { B cell } \\
\text { depletion } \\
\text { (months) }\end{array}$ & $\begin{array}{l}\text { Total } \\
\text { duration } \\
\text { of disease } \\
\text { (years) }\end{array}$ \\
\hline 1 & M & 2.9 & 0 & 5 & 35 & No & CI & RTX & 2 & 2.1 & 3.1 \\
\hline 2 & M & 6.9 & 0 & 7 & 30 & No & CYC,MMF,CI,LEV & RTX & 1 & 3.1 & 3.9 \\
\hline 3 & M & 2.9 & 0 & 15 & 40 & No & MMF,CI & RTX & 1 & 4.8 & 6.5 \\
\hline 4 & M & 1.6 & 3 & 8 & 60 & Yes & MMF,CI,LEV & RTX,OFAT & 5 & 27.3 & 12.1 \\
\hline 5 & M & 6.8 & 3 & 7 & 60 & Yes & MMF,CI & RTX & 2 & 6.5 & 4.2 \\
\hline 6 & $\mathrm{~F}$ & 3.5 & 0 & 12 & 5 & No & CYC,MMF,CI,LEV & RTX & 3 & 11.7 & 11.2 \\
\hline 7 & M & 1.5 & 0 & 12 & 25 & No & CYC,MMF,CI,LEV & RTX & 1 & 6.9 & 17.2 \\
\hline 8 & M & 1.9 & 0 & 16 & 50 & No & MMF,CI,LEV & RTX & 2 & 24.6 & 8.4 \\
\hline 9 & M & 5.6 & 0 & 9 & 30 & No & MMF,CI,LEV & RTX & 2 & 7.1 & 9.0 \\
\hline 10 & M & 3.4 & 0 & 10 & 60 & Yes & $\mathrm{MMF}, \mathrm{CI}$ & RTX,OFAT & 4 & 42.1 & 7.1 \\
\hline 11 & M & 4.7 & 3 & 6 & 30 & No & MMF,LEV & RTX & 2 & 13.3 & 6.5 \\
\hline 12 & M & 1.9 & 0 & 16 & 30 & No & MMF,CI,LEV & RTX,OFAT & 4 & 33.3 & 9.1 \\
\hline 13 & M & 1.7 & 0 & 9 & 15 & No & $\mathrm{MMF}, \mathrm{CI}$ & RTX & 1 & 7.8 & 14.1 \\
\hline 14 & M & 6.4 & 0 & 6 & 60 & Yes & CI & RTX,OBI & 3 & 13.9 & 2.7 \\
\hline
\end{tabular}

$F$ female; $M$ male; $n$ number; $I V M P$ intravenous methylprednisolone; $I S$ immunosuppressive (drugs); $C I$ calcineurin inhibitors (cyclosporine or tacrolimus); $C Y C$ cyclophosphamide; $M M F$ mycophenolate mofetil; $L E V$ levamisole; $R T X$ rituximab; OFAT ofatumumab; $O B I$ obinutuzumab

previously received at least one course of B cell depletion using a monoclonal antiCD20 IgG antibody (Table 1 and supplemental Table S1). Overall, 34 attempts at B cell depletion were undertaken in the 14 patients reported here: 2 patients had a single attempt at B cell depletion but displayed immediate relapse following $\mathrm{B}$ cell repletion (\#2,\#3), 2 patients had a single attempt at $\mathrm{B}$ cell depletion and delayed relapses 11 and 13 months after B cell repletion, respectively (\#7, \#13), 4 patients had 2 attempts at $\mathrm{B}$ cell depletion that failed to maintain remission (\#1, \#5, \#9, \#11), and 6 patients had multiple unsuccessful attempts of B cell depletion with a cumulative duration exceeding 12 months (\#4, \#6, \#8, \#10,\#12,\#14).

Table 2 Characteristics of the patients at treatment by obinutuzumab and daratumumab

\begin{tabular}{|c|c|c|c|c|c|c|c|c|c|c|c|}
\hline \# & $\begin{array}{l}\text { Age at } \\
\text { treatment } \\
\text { (years) }\end{array}$ & $\begin{array}{l}\text { Oral IS } \\
\text { drugs at } \\
\text { treatment }\end{array}$ & $\begin{array}{l}\text { Weight } \\
(\mathrm{kg})\end{array}$ & $\begin{array}{l}\text { Height } \\
(\mathrm{cm})\end{array}$ & $\begin{array}{l}\text { Body } \\
\text { surface } \\
\left(\mathrm{m}^{2}\right)\end{array}$ & $\begin{array}{l}\text { Dose } \\
\text { OBI } \\
(\mathrm{mg})\end{array}$ & $\begin{array}{l}\text { Dose } \\
\text { DAR } \\
(\mathrm{mg})\end{array}$ & $\begin{array}{l}\text { Time to oral IS } \\
\text { withdrawal } \\
\text { (weeks) }\end{array}$ & $\begin{array}{l}\text { Duration of B cell } \\
\text { depletion } \\
\text { (months) }\end{array}$ & $\begin{array}{l}\text { Status at } \\
\text { last } \\
\text { follow-up }\end{array}$ & $\begin{array}{l}\text { Duration of } \\
\text { remission after OBI } \\
\text { (months) }\end{array}$ \\
\hline 1 & 6.0 & FK & 20 & 112 & 0.79 & 445 & 445 & 6.4 & 8.1 & Remission & 24.6 \\
\hline 2 & 10.9 & PRED & 41 & 147 & 1.29 & 700 & 700 & 5.4 & 9.3 & Relapse & 21.7 \\
\hline 3 & 9.5 & PRED,NEO & 42 & 137 & 1.27 & 750 & 800 & 9.7 & 9.2 & Remission & 23.5 \\
\hline 4 & 13.7 & FK & 47 & 167 & 1.46 & 820 & 820 & 17.1 & 13.4 & Remission & 23.3 \\
\hline 5 & 10.9 & PRED & 40 & 148 & 1.28 & 750 & 750 & 4.6 & 11.6 & Remission & 23.2 \\
\hline 6 & 14.7 & PRED & 50 & 160 & 1.49 & 870 & 870 & 4.4 & 14.9 & Remission & 22.4 \\
\hline 7 & 18.8 & PRED & 60 & 175 & 1.70 & 1000 & 1000 & 6.1 & 13.6 & Remission & 21.6 \\
\hline 8 & 10.3 & FK & 39 & 149 & 1.27 & 700 & 700 & 3.0 & 9.1 & Relapse & 10.1 \\
\hline 9 & 14.7 & FK & 69 & 156 & 1.75 & 900 & 900 & 4.7 & 10.8 & Remission & 19.8 \\
\hline 10 & 10.5 & PRED,FK & 37 & 131 & 1.17 & 700 & 680 & 4.1 & 9.8 & Relapse & 11.1 \\
\hline 11 & 11.2 & PRED,FK & 23 & 134 & 0.91 & 600 & 600 & 5.7 & 7.6 & Relapse & 10.8 \\
\hline 12 & 11.0 & PRED,FK & 44 & 147 & 1.34 & 230 & 770 & 5.9 & 8.2 & Remission & 13.9 \\
\hline 13 & 15.7 & PRED & 44 & 164 & 1.40 & 750 & 750 & 4.7 & 9.7 & Remission & 13.0 \\
\hline 14 & 9.1 & PRED,FK & 30 & 135 & 1.06 & 580 & 580 & 14.1 & 8.7 & Relapse & 10.0 \\
\hline
\end{tabular}

IS Immunosuppressive (drugs); FK tacrolimus; NEO cyclosporine; PRED prednisone; $O B I$ obinutuzumab; DAR daratumumab 
Median age at treatment was 11.0 years (IQR 10.4-14.4), and median duration since NS onset was 7.8 years (IQR 4.817.0). Detectable EBV replication was observed in 4 patients (\#1, \#9, \#11,\#14) and CMV in one (\#8). PCR for BK and JC viruses were negative at start of the OD sequence in all patients.

\section{Oral drugs}

At the time of obinutuzumab infusion, all patients had been recently treated for a relapse, and were in remission under oral drugs: 5 under prednisone alone, 4 under tacrolimus alone, and 5 under prednisone and tacrolimus (Table 2). We treated 4 patients with tacrolimus alone at the time of relapse to maintain statural growth in 3 patients $(\# 4, \# 8, \# 9$ ) and because of a history of severe psychiatric issues under high dose of prednisone in one (\#1). Median time to oral drugs withdrawal was 5.6 weeks (IQR 4.6-6.4) after obinutuzumab infusion.

\section{Relapse-free survival}

All 14 patients experienced prolonged B cell depletion with a median time to B cell recovery of 9.5 months (IQR 8.9-12.1) (Supplemental Fig. S1). The 2-year relapse-free survival was $60 \%$ after the OD sequence (Fig. 1). No significant differences in relapse-free survival rates were found between patients with or without an episode of secondary steroid resistance (Supplemental Fig. S2). Similarly, treatment of the last relapse with tacrolimus alone had no impact (Supplemental Fig. S3). Nine out of 14 patients remain in remission with a median follow-up time of 22.5 months (IQR 19.9-23.3) from the injection of obinutuzumab (Fig. 1) and a median time of 9.1 (IQR 8.0-11.7) months after B cell repletion (Supplemental Fig. S4). These 9 patients maintain stable remission despite the withdrawal of all oral immunosuppression for a median

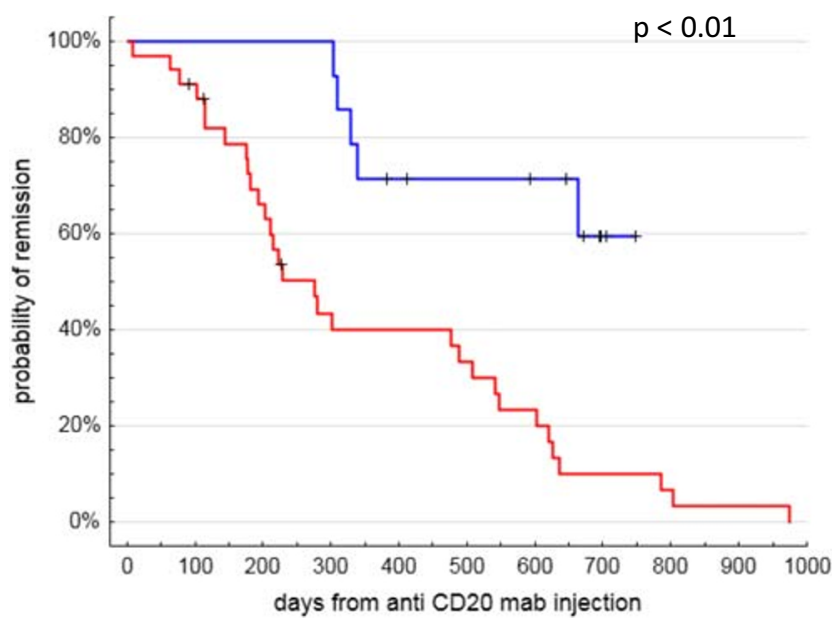

Fig. 1 Probability of remission following anti CD20 monoclonal antibodies in 34 previous attempts of B cell depletion (red line) vs. after obinutuzumab injection in the 14 patients (blue line) time of 20.2 (IQR 18.8-21.4) months (Supplemental Fig. S5). A relapse occurred in 5 patients (\#2, \#8, \#10, \#11, \#14), 4 relapsed early within 100 days following B cell recovery while one relapse later within the first year.

We compared the outcomes following the OD sequence with the ones following the 34 previous attempts at B cell depletion (Fig. 1 and Supplemental Figs. S1, S4, S5). The median time of continuous B cell depletion was 4.0 months [IQR 3.3-6.7] following the 34 previous $B$ cell depletions and 9.5 [IQR 8.9-12.1] $(p<0.05)$ after the OD sequence. Consistently, the probability of remission at month 6 , month 12 , and month 24 after OD sequence and anti-CD20 alone were 100.0 vs. $53.5 \%, 78.6$ vs. $40.5 \%$, and 59.5 vs. $10.1 \%$, respectively (Fig. 1). Moreover, the probability of remission after B cell repletion after OD sequence and antiCD20 alone at month 6 , month 12 , and month 18 was 69.6 vs. $23.6 \%, 69.6$ vs. $10.1 \%$, and 49.7 vs. $6.7 \%$, respectively (Supplemental Fig. S4). In terms of direct patient benefit, the median time without oral immunosuppression was 4.4 months [IQR 1.0-11.0] in the previous B cell depletions and 19.1 months [IQR 10.6$21.1]$ in the OD sequence $(p<0.001)$.

\section{Tolerance}

Mild infusion-related reactions were reported in 3 patients during obinutuzumab infusion: vomiting $(\# 4, \# 10)$ and urticaria (\#3), and in 4 patients during daratumumab infusion: mild transient bronchospasm, throat itching and labial edema (\#2, \#12, \#13, \#14).

Asymptomatic neutropenia below $1500 / \mathrm{mm}^{3}$ was transiently observed by months 1,4 , and 12 in 2 patients (\#3, \#9) and did not require any specific treatment. However, a decrease of neutrophils was detected in 7 additional patients with a nadir ranging from 1760 to $2310 / \mathrm{mm}^{3}$. By contrast, an expansion of the CD8 $\mathrm{T}$ cells was observed after the OD sequence, while CD4 T cells were unaffected (Supplemental Figs. S4 and S5). Eighteen months after the OD sequence and 6 months after complete B cell repletion, patient \#5 developed Covid-19 along with his parents and all siblings. He displayed isolated fever during $36 \mathrm{~h}$ and fully recovered without any respiratory signs. No other infections were reported.

\section{Hypogammaglobulinemia}

At INS onset, all patients had normal plasma concentrations of immunoglobulins when in remission. By contrast, as a result of previous immunosuppression and B cell depletions, 2 patients displayed a decrease in plasma immunoglobulin $G$ (IgG) levels (\#7, \#10), 4 a significant decrease of plasma immunoglobulin A ( $\mathrm{IgG})(\# 4, \# 7$, \#8, \#9), and one had undetectable plasma $\operatorname{IgA}(\# 13)$ prior to the OD sequence. One patient with hypoIgA had an increased plasma level of $\operatorname{IgG}(\# 4)$. Another patient had an isolated increased level of plasma 
$\operatorname{IgA}(\# 5)$. The immunoglobulin profile was normal in the other 7 patients.

As expected, all patients experienced a decrease in the level of circulating immunoglobulins following the OD sequence (Fig. 2a-c) including a complete disappearance of immunoglobulin $\mathrm{M}(\mathrm{IgM})$ in 9 patients. Circulating IgM reappeared within 1 to 8 months in all patients but one, who had undetectable circulating levels. Similarly, IgA was undetectable in 3 patients ( 2 with previously low plasma level and one with a complete lack of IgA at start of the OD sequence). IgA remained undetectable in these 3 patients at last follow-up.
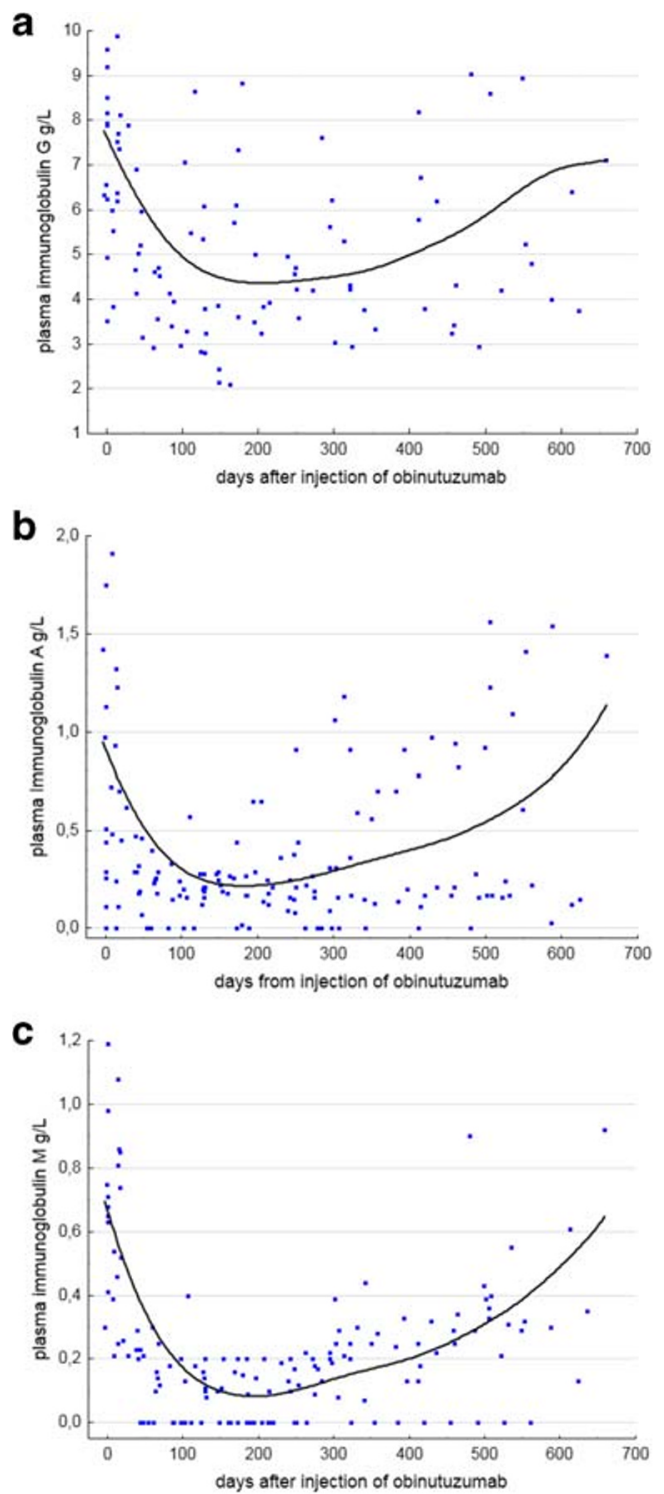

Fig. 2 Time course of the plasma level of immunoglobulin $\mathrm{G}$ (IgG) (graph a; $n=101$ ), immunoglobulin A (IgA) (graph $\mathrm{b} ; n=150)$, immunoglobulin M (IgM) (graph c; $n=150)$ from obinutuzumab injection. Obviously, 49 points of plasma IgG obtained within 10 weeks from intravenous polyclonal $\mathrm{IgG}$ infusion have been discarded in order to analyze the spontaneous course of the level of plasma IgG. The regression lines have been obtained by the weighted least squares method
The other eleven patients with normal plasma IgA at the start experienced a decrease of plasma IgA below the normal value in the months following the OD sequence and five had persistent low plasma IgA levels at last follow-up, while 6 fully recovered (Fig. 2b).

Although all patients experienced a decrease in circulating $\mathrm{IgG}$, the lowest level of plasma $\operatorname{IgG}$ was $2 \mathrm{~g} / \mathrm{L}$ in one patient (\#10) and ranged from 3 to $6 \mathrm{~g} / \mathrm{L}$ in all other patients. Of note, all patients who had normal immunoglobulin levels before treatment fully recovered normal immunoglobulin levels after B cell repletion. Only 2 patients remained with low plasma IgG levels at last follow-up. In order to prevent severe infections, 3 patients received a systematic supplementation with intravenous polyclonal $\operatorname{IgG}$ every month in order to maintain the level of plasma IgG over $5 \mathrm{~g} / \mathrm{L}$. In 9 other patients, intravenous polyclonal immunoglobulin was given intermittently when the plasma level of IgG dropped below $4 \mathrm{~g} / \mathrm{L}$. Two patients did not require any immunoglobulin supplementation.

\section{Discussion}

Maintaining sustained remission in patients with SDNS remains a challenge. Here, we report the outcomes following the association of obinutuzumab and daratumumab to induce stable remission and allow withdrawal of oral immunosuppressive drugs in patients with uncontrolled SDNS despite previous treatments including $\mathrm{B}$ cell depletion.

Obinutuzumab is a second generation antiCD20 monoclonal antibody targeting naïve and memory B cells. It was designed to overcome resistance to rituximab in the treatment of B cell malignancies. While rituximab relocalizes CD20 to lipid rafts and induces significant complement-dependent cytotoxicity, obinutuzumab has a powerful antibody-dependent cytotoxicity and can evoke greater direct cell death by mechanisms that are largely caspase-independent. In detail, obinutuzumab is able to overcome the low affinity of certain polymorphisms of the FcGamma receptor 3A on effector cells, hence improving antibody-dependent cytotoxicity in a greater proportion of patients. Clinically, obinutuzumab induces more profound and lasting remission, with an almost twofold higher complete response rate in patients treated for indolent nonHodgkin lymphoma [15] and may also be more efficient than rituximab in autoimmune diseases [16-18].

Daratumumab is a human monoclonal antibody that targets CD38. Its multifaceted mechanisms of action include direct plasma cell cytotoxicity and an immunomodulatory component that results in depletion of immunosuppressive cells and clonal expansion of cytotoxic T cells. Although daratumumab has been designed for the therapy of multiple myeloma [19], its use has been successfully reported, combined with rituximab, in pediatric patients with refractory autoimmune 
hemolytic anemia [16, 17], and in adults for HLAdesensitization prior to kidney transplantation [18].

In this small series of 14 patients, the combination of obinutuzumab and daratumumab was both effective and safe, when associated with a preventive treatment of infections with sulfamethoxazole and $\operatorname{IgG}$ infusion in case of hypogammaglobulinemia. A $60 \%$ relapse-free survival at 2 years in severe SDNS patients without oral immunosuppressive drugs is a very encouraging preliminary result that surpasses the results of both conventional oral treatments and rituximab alone $[4,5,20,21]$. The specific role of each monoclonal antibody of the OD sequence will deserve further investigation. The efficacy of this treatment is likely due to the extended $\mathrm{B}$ cell depletion induced by a single dose of $1000 \mathrm{mg} / 1.73 \mathrm{~m}^{2}$ of obinutuzumab since none of the patients relapsed during the phase of $\mathrm{B}$ cell depletion. However, this alone may not fully explain the sustained effect observed in the majority of the patients even months after B cell recovery. This finding supports the hypothesis of a beneficial effect of daratumumab that deserves further exploration.

No severe infectious events happened in our study although one patient developed the Covid-19. Yet, all patients decreased their plasma levels of one or more immunoglobulin classes. Three major observations deserve attention in this study. First, IgG never reached a level below $2 \mathrm{~g} / \mathrm{L}$, indicating the persistence of well protected plasma cells that are functional and able to produce IgG. Second, in most patients, the level of circulating immunoglobulins returned to normal within 2 years. Third, a majority of patients had transiently undetectable plasma IgM levels after treatment. This raises concerns over their ability to develop a naïve immune response if infected with a previously unmet pathogen [22] and supports the need for supplementation of $\mathrm{IgG}$ during at least 18 months after treatment in order to prevent severe infections, especially infection by enteroviruses [23]. Postvaccination serologies after B cell reconstitution and vaccine reimmunization are also mandatory at a distance from $\mathrm{B}$ cell repletion, as already suggested after any B cell depletion course in children [24]. Of note, oral immunosuppressive drugs have been shown to decrease circulating immunoglobulin levels in up to $65 \%$ of patients with INS [24]. Moreover, oral immunosuppressive drugs, especially when a combination of steroids, CNI and antimetabolites are used, impair all components of immunity, including innate and adaptive immunity, and the $\mathrm{T}$ cell-mediated continuous monitoring process by which invading pathogens and tumoral cells are recognized and eliminated. This explains the high prevalence of skin carcinoma in transplanted patients [25].

The rationale of the OD sequence to control difficult-totreat steroid-dependent patients was based on the central role of B cell immunity. The pathophysiology of INS remains elusive but many clinical facts and results from translational studies support the evidence of a circulating glomerular permeability factor of immune origin. Despite its major effect on the kidney excretion of albumin, attempts to precisely identify this factor have failed. The first attempt to understand the whole complexity of the disease was undertaken by Shimada and Garin [26] who suggested a 2-hit podocyte immune disorder based on the high expression of TLR3 in podocytes. They hypothesized that the stimulation of TLR3 by viral or bacterial antigens induces an abnormal persistence of CD80 expression and a subsequent loss of podocyte integrity due to the action of specific circulating cytokines during infections. Following the demonstration of the ability of antiCD20 monoclonal antibodies to maintain remission [5], other mechanisms have been suggested to accommodate this new clinical fact. First, the effect of rituximab on nephrotic syndrome was supposed to be due to an off-target binding to sphingomyelinphosphodiesterase-acid-like-3b expressed on podocytes [27]. The major limit of this hypothesis is that rituximab does not bind to sphingomyelin-phosphodiesterase-acid-like-3b in vivo and the binding previously reported is a fixation artifact [28]. Moreover, fixation of other antiCD20 monoclonals on glomerular substructure has never been reported so far. Because no glomerular immunoglobulin deposits are observed on biopsies of INS patients, most authors are legitimately reluctant to consider a direct effect of B cell depletion and impairment of antibody production and support the notion that the beneficial effect of rituximab is mediated by the B-T cooperation through indirect pathways affecting $\mathrm{T}$ cell functions [3, 29].

However, this hypothesis ignores the physiological transcellular flow of antibodies through the podocyte [30] that may be at the origin of a loss of podocyte integrity without visible deposits on immunofluorescence. Precisely, the following hypothesis is based on a 2-hit podocyte immune disorder due to EBV infection involving the antibody flow through the podocytes. Recently, the association of the first flare with EBV DNA replication [31], the fact that memory B cell reconstitution is the earliest biomarker of INS relapse and the site of EBV latency [32,33], as well as a common genetic locus between SSNS and the genetic regulation of antiEBNA1 IgG antibodies [34], suggest a close association between EBV infection and the disease. Indeed, EBV infection may have an impact on podocytes through 2 mechanisms. First, EBV generates numerous noncoding RNAs involved in the virus cycle. All those RNAs, including EBER1 and EBER2 are powerful TLR3 agonists [35] susceptible to interact with TLR3 expressed on the podocyte and to affect podocyte integrity in a similar way as previously described by Shimada and Garin. Moreover, the transmission of proteinuria to mice by antiUCHL1 IgG antibodies purified from a relapsing patient [36], as well as the efficacy of immunoglobulin adsorption in the multiresistant forms of INS [37] are also relevant arguments to involve antibodies as the second podocyte hit that leads to massive proteinuria. It turns out that EBNA1 and 
UCHL1 share two short peptide sequences located in the immunogen domain of EBNA1 and in close vicinity at the surface of UCHL1 (blast in https://web.expasy.org/sim/; reference of protein sequences: YP_401677.1 and NP 004172.2 respectively). Interestingly, UCHL1 is a deubiquitination enzyme involved in the podocyte balance of autophagy [38] and is massively overexpressed in podocytes during all glomerular diseases with massive proteinuria in humans except one, namely idiopathic nephrotic syndrome [39]. Consistently, the combination of obinutuzumab and daratumumab is not only targeting the production of IgG antibodies through the deletion of memory B cells and differentiated memory plasma cells, but is also affecting the EBV latency and lytic cycle: memory B cells are the location of EBV latency and lifelong persistence of the virus in the immune system, while plasma cells are the mandatory step for the EBV lytic cycle and virus multiplication [33] (Supplemental Fig. S8).

In conclusion, a combination of therapeutic monoclonal antibodies targeting the B cell system and the production of antibodies might be effective to disrupt the chronic forms of INS. However, a formal demonstration with a randomized control trial comparing obinutuzumab alone versus the OD sequence is mandatory prior to expanding this strategy. These results further support the first line role of B cells and antibodies in the pathophysiology of INS.

\section{Compliance with ethical standards}

Conflict of interest The authors declare that they have no conflict of interest.

\section{References}

1. Dossier C, Delbet JD, Boyer O, Daoud P, Mesples B, Pellegrino B, See H, Benoist G, Chace A, Larakeb A, Hogan J, Deschenes G (2019) Five-year outcome of children with idiopathic nephrotic syndrome: the NEPHROVIR population-based cohort study. Pediatr Nephrol 34:671-678

2. Fakhouri F, Bocquet N, Taupin P, Presne C, Gagnadoux MF, Landais P, Lesavre P, Chauveau D, Knebelmann B, Broyer M, Grunfeld JP, Niaudet P (2003) Steroid-sensitive nephrotic syndrome: from childhood to adulthood. Am J Kidney Dis 41:550-557

3. Vivarelli M, Massella L, Ruggiero B, Emma F (2017) Minimal change disease. Clin J Am Soc Nephrol 12:332-345

4. Azib S, Macher MA, Kwon T, Dechartres A, Alberti C, Loirat C, Deschenes G, Baudouin V (2011) Cyclophosphamide in steroiddependent nephrotic syndrome. Pediatr Nephrol 26:927-932

5. Iijima K, Sako M, Nozu K, Mori R, Tuchida N, Kamei K, Miura K, Aya K, Nakanishi K, Ohtomo Y, Takahashi S, Tanaka R, Kaito H, Nakamura H, Ishikura K, Ito S, Ohashi Y (2014) Rituximab for childhood-onset, complicated, frequently relapsing nephrotic syndrome or steroid-dependent nephrotic syndrome: a multicentre, double-blind, randomised, placebo-controlled trial. Lancet 384 : 1273-1281
6. Sellier-Leclerc AL, Baudouin V, Kwon T, Macher MA, Guerin V, Lapillonne H, Deschenes G, Ulinski T (2012) Rituximab in steroiddependent idiopathic nephrotic syndrome in childhood-follow-up after CD19 recovery. Nephrol Dial Transplant 27:1083-1089

7. Zagury A, de Oliveira AL, de Moraes CA, de Araujo Montalvao JA, Novaes RH, de Sa VM, Monteiro de Carvalho DB, Matuck T (2011) Long-term follow-up after cyclophosphamide therapy in steroid-dependent nephrotic syndrome. Pediatr Nephrol 26:915920

8. Dorner T, Jacobi AM, Lipsky PE (2009) B cells in autoimmunity. Arthritis Res Ther 11:247

9. Fassbinder T, Saunders U, Mickholz E, Jung E, Becker H, Schluter B, Jacobi AM (2015) Differential effects of cyclophosphamide and mycophenolate mofetil on cellular and serological parameters in patients with systemic lupus erythematosus. Arthritis Res Ther $17: 92$

10. DiLillo DJ, Hamaguchi Y, Ueda Y, Yang K, Uchida J, Haas KM, Kelsoe G, Tedder TF (2008) Maintenance of long-lived plasma cells and serological memory despite mature and memory B cell depletion during CD20 immunotherapy in mice. J Immunol 180: 361-371

11. Crickx E, Weill J, Reynaud C, Mahévas M (2020) Anti-CD20mediated B-cell depletion in auto-immune diseases: successes, failures and future perspectives. Kidney Int 97:885-893

12. Blumberg RW, Cassady HA (1947) Effect of measles on the nephrotic syndrome. Am J Dis Child 73:151-166

13. Gairdner D (1978) A notable case of nephrosis. Arch Dis Child 53: 363-365

14. Mina MJ, Kula T, Leng Y, Li M, de Vries RD, Knip M, Siljander H, Rewers M, Choy DF, Wilson MS, Larman HB, Nelson AN, Griffin DE, de Swart RL, Elledge SJ (2019) Measles virus infection diminishes preexisting antibodies that offer protection from other pathogens. Science 366:599-606

15. Freeman CL, Sehn LH (2018) A tale of two antibodies: obinutuzumab versus rituximab. Br J Haematol 182:29-45

16. Cooling L, Hugan S (2019) Daratumumab in combination with standard treatment for autoimmune hemolytic anemia in a pediatric patient. Transfusion 59:3801-3802

17. Even-Or E, Naser Eddin A, Shadur B, Dinur Schejter Y, Najajreh M, Zelig O, Zaidman I, Stepensky P (2020) Successful treatment with daratumumab for post-HSCT refractory hemolytic anemia. Pediatr Blood Cancer 67:e28010

18. Kwun J, Matignon M, Manook M, Guendouz S, Audard V, Kheav D, Poullot E, Gautreau C, Ezekian B, Bodez D, Damy T, Faivre L, Menouch D, Yoon J, Park J, Belhadj K, Chen D, Bilewski AM, Yi JS, Collins B, Stegall M, Farris AB, Knechtle S, Grimbert P (2019) Daratumumab in sensitized kidney transplantation: potentials and limitations of experimental and clinical use. J Am Soc Nephrol 30: 1206-1219

19. Mateos MV, Dimopoulos MA, Cavo M, Suzuki K, Jakubowiak A, Knop S, Doyen C, Lucio P, Nagy Z, Kaplan P, Pour L, Cook M, Grosicki S, Crepaldi A, Liberati AM, Campbell P, Shelekhova T, Yoon SS, Iosava G, Fujisaki T, Garg M, Chiu C, Wang J, Carson R, Crist W, Deraedt W, Nguyen H, Qi M, San-Miguel J (2018) Daratumumab plus bortezomib, melphalan, and prednisone for untreated myeloma. N Engl J Med 378:518-528

20. Gellermann J, Weber L, Pape L, Tonshoff B, Hoyer P, Querfeld U (2013) Mycophenolate mofetil versus cyclosporin A in children with frequently relapsing nephrotic syndrome. J Am Soc Nephrol 24:1689-1697

21. Ishikura K, Yoshikawa N, Hattori S, Sasaki S, Iijima K, Nakanishi K, Matsuyama T, Yata N, Ando T, Honda M (2010) Treatment with microemulsified cyclosporine in children with frequently relapsing nephrotic syndrome. Nephrol Dial Transplant 25:39563962 
22. Kridin K, Ahmed AR (2020) Post-rituximab immunoglobulin M (IgM) hypogammaglobulinemia. Autoimmun Rev 19:102466

23. Sellier-Leclerc AL, Belli E, Guerin V, Dorfmuller P, Deschenes G (2013) Fulminant viral myocarditis after rituximab therapy in pediatric nephrotic syndrome. Pediatr Nephrol 28:1875-1879

24. Colucci M, Carsetti R, Serafinelli J, Rocca S, Massella L, Gargiulo A, Lo Russo A, Capponi C, Cotugno N, Porzio O, Onetti Muda A, Palma P, Emma F, Vivarelli M (2019) Prolonged impairment of immunological memory after anti-CD20 treatment in pediatric idiopathic nephrotic syndrome. Front Immunol 10:1653

25. Plasmeijer EI, Sachse MM, Gebhardt C, Geusau A, Bouwes Bavinck JN (2019) Cutaneous squamous cell carcinoma (cSCC) and immunosurveillance - the impact of immunosuppression on frequency of cSCC. J Eur Acad Dermatol Venereol 33(Suppl 8): 33-37

26. Shimada M, Araya C, Rivard C, Ishimoto T, Johnson RJ, Garin EH (2011) Minimal change disease: a "two-hit" podocyte immune disorder?. Pediatric Nephrology 26 (4):645-649

27. Fornoni A, Sageshima J, Wei C, Merscher-Gomez S, AguillonPrada R, Jauregui AN, Li J, Mattiazzi A, Ciancio G, Chen L, Zilleruelo G, Abitbol C, Chandar J, Seeherunvong W, Ricordi C, Ikehata M, Rastaldi MP, Reiser J, Burke GW 3rd (2011) Rituximab targets podocytes in recurrent focal segmental glomerulosclerosis. Sci Transl Med 3:85ra46

28. Kim AH, Chung JJ, Akilesh S, Koziell A, Jain S, Hodgin JB, Miller MJ, Stappenbeck TS, Miner JH, Shaw AS (2017) B cell-derived IL4 acts on podocytes to induce proteinuria and foot process effacement. JCI Insight 2:e81836

29. Chambers ET, Gbadegesin RA (2019) Aberrant IgM on T cells: biomarker or pathogenic factor in childhood nephrotic syndrome? Kidney Int 96:818-820

30. Roopenian DC, Akilesh S (2007) FcRn: the neonatal Fc receptor comes of age. Nat Rev Immunol 7:715-725

31. Dossier C, Sellier-Leclerc AL, Rousseau A, Michel Y, GautheretDejean A, Englender M, Madhi F, Charbit M, Ulinski T, Simon T, Jacqz-Aigrain E, Deschenes G (2014) Prevalence of herpesviruses at onset of idiopathic nephrotic syndrome. Pediatr Nephrol 29: 2325-2331

32. Colucci M, Carsetti R, Cascioli S, Casiraghi F, Perna A, Rava L, Ruggiero B, Emma F, Vivarelli M (2016) B cell reconstitution after rituximab treatment in idiopathic nephrotic syndrome. J Am Soc Nephrol 27:1811-1822

33. Thorley-Lawson DA (2015) EBV persistence-introducing the virus. Curr Top Microbiol Immunol 390:151-209

34. Gbadegesin RA, Adeyemo A, Webb NJ, Greenbaum LA, Abeyagunawardena A, Thalgahagoda S, Kale A, Gipson D, Srivastava T, Lin JJ, Chand D, Hunley TE, Brophy PD, Bagga A, Sinha A, Rheault MN, Ghali J, Nicholls K, Abraham E, Janjua HS, Omoloja A, Barletta GM, Cai Y, Milford DD, O'Brien C, Awan A, Belostotsky V, Smoyer WE, Homstad A, Hall G, Wu G, Nagaraj S, Wigfall D, Foreman J, Winn MP (2015) HLA-DQA1 and PLCG2 are candidate risk loci for childhood-onset steroid-sensitive nephrotic syndrome. J Am Soc Nephrol 26:1701-1710

35. Shiyue C, Zhi L, Junju H, Shujun F, Yumei D, Qin Z, Yuanliang Y, Xiaoyu L, Liyu L, Chang F, Lu Z, Jiang H, Yuezhen D, Lun-Quan S (2019) Epstein-Barr virus noncoding RNAs from the extracellular vesicles of nasopharyngeal carcinoma (NPC) cells promote angiogenesis via TLR3/RIG-I-mediated VCAM-1 expression. Biochimica et Biophysica Acta (BBA) - Molecular Basis of Disease 1865 (6):1201-1213

36. Jamin A, Berthelot L, Couderc A, Chemouny JM, Boedec E, Dehoux L, Abbad L, Dossier C, Daugas E, Monteiro RC, Deschenes G (2018) Autoantibodies against podocytic UCHL1 are associated with idiopathic nephrotic syndrome relapses and induce proteinuria in mice. J Autoimmun 89:149-161

37. Nattes E, Karaa D, Dehoux L, Peuchmaur M, Kwon T, Deschenes G (2019) Remission of proteinuria in multidrug-resistant idiopathic nephrotic syndrome following immunoglobulin immunoadsorption. Acta Paediatr 108:757-762

38. Meyer-Schwesinger C (2019) The ubiquitin-proteasome system in kidney physiology and disease. Nat Rev Nephrol 15:393-411

39. Meyer-Schwesinger C, Meyer TN, Munster S, Klug P, Saleem M, Helmchen U, Stahl RA (2009) A new role for the neuronal ubiquitin C-terminal hydrolase-L1 (UCH-L1) in podocyte process formation and podocyte injury in human glomerulopathies. J Pathol 217: $452-464$

Publisher's note Springer Nature remains neutral with regard to jurisdictional claims in published maps and institutional affiliations. 